\title{
Alpha-(1,3)-Fucosyltransferase 4
}

National Cancer Institute

\section{Source}

National Cancer Institute. Alpha-(1,3)-Fucosyltransferase 4. NCI Thesaurus. Code C104402.

Alpha-(1,3)-fucosyltransferase $4(530 \mathrm{aa}, \sim 60 \mathrm{kDa})$ is encoded by the human FUT 4 gene.

This protein is involved in the generation of fucosylated carbohydrate structures. 